\title{
The world's oldest fossil seal record
}

\section{Cajus Diedrich}

PaleoLogic, Research Institute, Halle, Germany; cdiedri@gmx.net

Received 12 September 2011; revised 22 October 2011; accepted 28 October 2011.

\begin{abstract}
A femur fragment with an Early Lutetian (early Middle Eocene) age is the world's oldest fossil record from a seal, and, is described as Praephoca bendullensis nov. gen. nov. spec. This find pushes back the earliest evolution of seals into the Paleocene epoch. The femur has plesiomorphic terrestrial mammal characteristics but has a morphology that is already closer to that of Miocene and present day seals. The Eocene seal femur was found at Fürstenau-Dalum in north-west Germany, in a conglomerate rich in shark teeth that was deposited in a coastal delta environment to the north-west of the central European Rhenish Massif mainland, in the southern pre-North Sea Basin. This discovery has led to a revision of the theory that phocids originated along the coastline of the North American continent. Instead they can now be interpreted to have originated in the tropical Eocene climate of central Europe. Although the fossil records of pinnipeds in Europe during the Eocene, Oligocene and Miocene are extremely sparse, they appear to have inhabited the preNorth Sea basin, within the influence of temperate and arctic upwellings. The distribution of abundant teeth from white and megatooth sharks of two different lineages appears to correlate with that of the seals, which the sharks most probably hunted; providing supporting evidence that the phocids were already adapted as shallow marine coastal inhabitants by this time.
\end{abstract}

Keywords: Oldest Seal Remains; Praephoca bendullensis Nov. Gen. Nov. Spec.; Giant Shark Predation; Middle Eocene; Shallow Marine Coastal Deltaic Influenced Habitats; Pre-Northsea Basin of Central Europe

\section{INTRODUCTION}

The oldest seals on planet Earth were thought to have appeared about 28 m.y. ago during the North American Oligocene [1], but more recent reports claim to have found an even younger (Miocene) "missing link" between terrestrial mammals and the basal pinnipeds in the Arctic [2]. DNA analyses on pinnipeds have, however, suggested an older (Eocene) age for their ancestors [3,4], but until now without any supporting fossil evidence.

A newly discovered seal femur from a recently excavated site at Fürstenau-Dalum in north-west Germany (Figures 1(a) and (b)) [5] and a review of other rare European remains of Oligocene age from the pre-North Sea basin have now combined to suggest a different scenario from that proposed by previous authors, who have suggested a basal pinniped evolution starting in, or along the coastline of, the North American landmass [4]. Neither the palaebiogeography nor the suggested (but unproven) Eocene age for the beginning of the evolution of evolution of earless seals (phocids) [3,4,6,7] can be supported by the evidence from this new fossil seal site in Germany. This vertebrate-rich site has been the subject of interdisciplinary studies; it contains mainly shark remains but also a variety of marine mammals [5]. Convincing evidence has been identified from this site of a "missing link" seal with a Middle Eocene or even older (Lower Eocene) age [5]. North-western Germany also provides insights into both the palaeoenvironment (Figure 1(b)) and the palaeoecology of these, the earliest (and already fully developed) seals in the world, as well as into their main predators, the ancestors of present-day white sharks and megatooth sharks [5].

Central Europe experienced a tropical climate during the Middle Eocene and many terrestrial mammal groups were already well developed at this time. These are, to date, mainly known from the German fluvial and freshwater lake sites at Messel and Geiseltal (Figure 1(a)) [8], from which no seal ancestors have been recorded, nor have any early phocids been reported from other Eocene marine vertebrate fossil localities of the European pre-North Sea basin in France, Belgium, or England (Figure 1(a)).

\section{MATERIALS AND METHODS}

A two-day excavation of a field site at Dalum was 

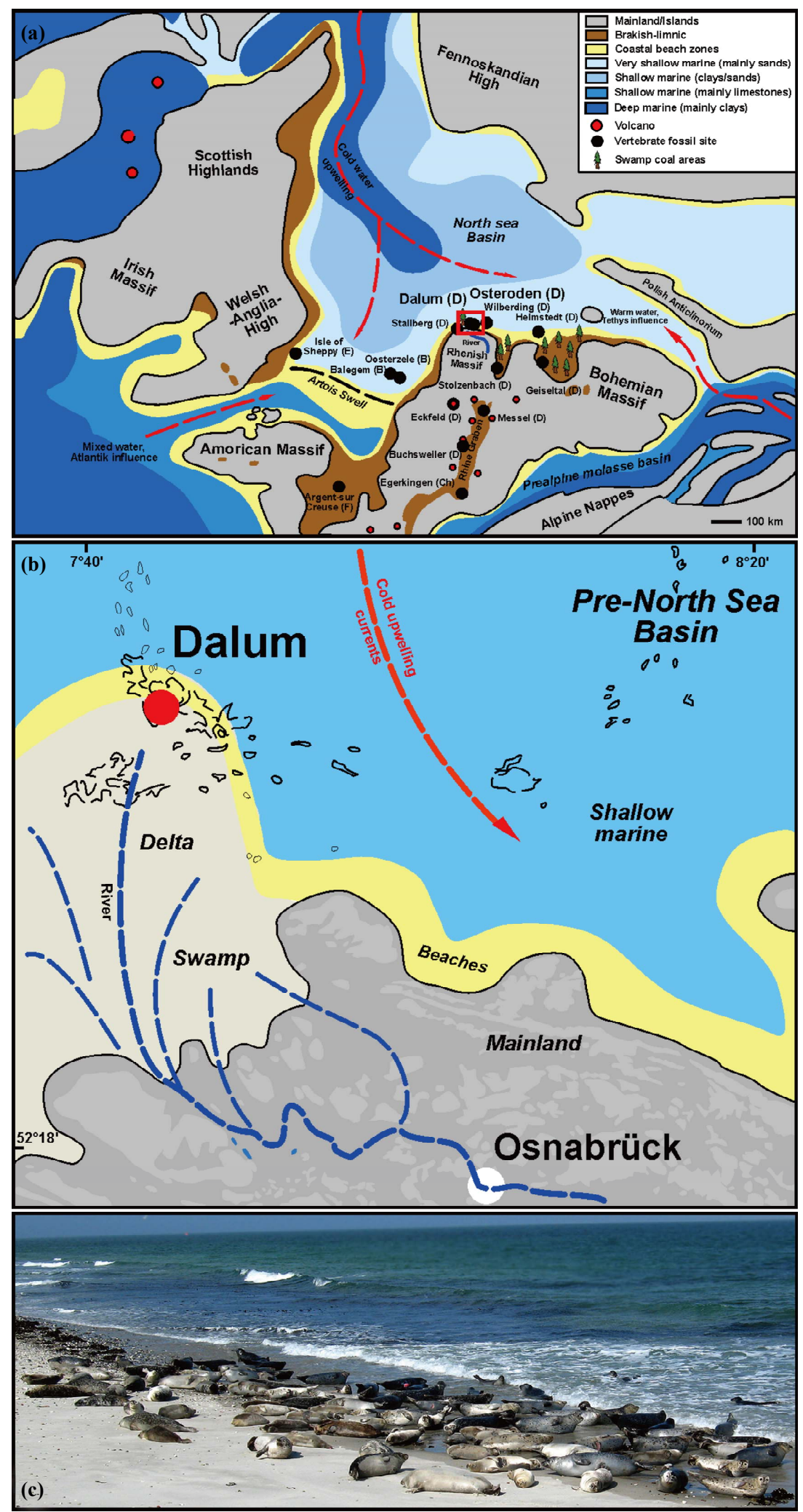

Figure 1. (a) Important Eocene marine and terrestrial vertebrate fossil sites in Europe; (b) Middle Eocene seal delta and beaches on the north-western Rhenish Massif, in the southern pre-North Sea basin; (c) Modern common seal Phoca vitulina Linnaeus, 1758 colony on the German Helgoland Düne sand bank (Photo A. Trepte). 
performed in May 2011, using large earth-moving machinery [5]. Sections were drawn up as part of stratigraphic and sedimentological studies on the Fürstenau Formation sequence at Dalum, which has been dated as Early Eocene (Ypresian) to basal Middle Eocene (Lutetian). A total of 180 cubic meters of phosphorite conglomerate from the early Lutetian transgression was obtained for sieving three size fractions using 1 and $4 \mathrm{~mm}$ sieves, the finer fraction being discarded. Only $0.1 \%$ of the recovered material has yet been sieved [5], but this has already yielded 14,440 fossils, of which $95 \%$ are sharks' teeth. Half of these 13,690 selachian teeth could be identified at species level. Less well represented are the teeth and fin spines of rays and the teeth and bones of bone fish. The finer material (less than $4 \mathrm{~mm}$ ) contains many additional species that remain to be examined in the future. Less then $0.1 \%$ of the fossils are from mammals and these are mostly highly fragmented and rounded usually rendering them impossible to identify. Several terrestrial mammals that were identified just from their teeth are similar to those in the Messel fauna and of similar age; they include early horses and tapirs [9]. Marine mammals have now also been identified, although only from their postcranial bones. At least one unidentified distal humerus fragment from a pachyostotic, marine mammal was found during this program, proving the significance of this site with regard to the evolution of marine mammals. The femur illustrated in Figure 2 was actually found was actually found in these gravels during the 1980s, and has prompted a major program seeking to understand the biodiversity of marine vertebrates in Europe during the Eocene, in relation to that of the terrestrial vertebrates. This femur, together with all material from the 2011 excavations, is housed in the Shark Center at Bippen (SCB) in north-west Germany, a public visitor center and museum in the UNESCOsupported "Geo and Naturpark TERRA. Vita". Other seal femora [10] have also been studied with respect to their measurements [11], including bone material in the University of Alaska Museum (UAM), Oligocene remains housed in the Dobergmuseum, Bünde (DMB) in Germany, Miocene material from the Oertijdmuseum de Groene Poort, Boxtel (MAB) in the Netherlands, and finally, modern seal remains from the southern North Sea Basin at the Seehundstation, Friedrichskoog (SFI) in Germany.

\section{THE WORLD'S EARLIEST PHOCID FOSSIL}

Suborder Pinnipedia Illiger, 1811

Family Phocidae Gray, 1821

Genus Praephoca nov. gen.

Praephoca bendullensis nov. spec.
Holotype. Half right femur (Figure 1(a)).

Type stratum. Marine transgression gravels of the Fürstenau Formation, Early Lutetian, early Middle Eocene, Paleogene, 45 - $49 \mathrm{Ma}$.

Type locality. Dalum, north-west Germany, southern pre-North Sea basin.

Holotype name. Genus after the ancestor of Phoca, and species after the collector J. Bendull.

Description and differential diagnosis. Only the upper half of the right femur is preserved (Figure 1). Compared with Oligocene, but mainly with Miocene to present-day phocid pinniped femora (Figures 2.2-2.4) the femur joint is much more prominent and its plesiomorphic character relates more to terrestrial mammals such as the Eocene mammals from Messel [8]. This prominence generally reduces during the evolution of phocids, as an aquatic adaptation (Figures 2.2-2.4) [10]. The double-headed and narrower trochanter tertius of the Eocene femur still has a low angle with the axis of the femur $\left(10^{\circ}\right)$, compared to the much larger angle $\left(30^{\circ}-40^{\circ}\right)$ in the Miocene to present-day phocids (Figures 2.2 and 2.3), which also have a flattened trochanter tertius. The Trochanter tertius of $P$. bendullensis has the plesiomorphic characteristics of terrestrial mammals. The already flattened and widened femur shaft (Figure 2.1(b)) is the main apomorphic character and is typical of highly evolved phocids that are already adapted to aquatic environments, as well as being found in Miocene to present-day pinnipeds (Figures 2.2-2.4) [10,11]. Overall this new Eocene femur reflects an intermediate stage between terrestrial mammals and the Miocene pinnipeds, already exhibiting well-developed phocid characteristics. Quite similar in shape to this Eocene femur are those of the modern arctic Phoca hispida Schreber, 1775 (Figure 2.4), and in particular, the common seal Phoca vitulina. Both of these present-day seals have a less distinct femur head, and are distally wider with a smaller distal tibia/ fibula articulation surface (Figures 2.3 and 2.4).

\section{DISCUSSION}

\subsection{The Evolutionary Beginnings of the Earliest Phocids}

The seal femur (Figure 2) is possibly even a little older than Middle Eocene, and may derive from reworked Lower Eocene marine sands [5], which would push back the evolution of pinnipeds at least into the Paleocene.

The femur has been compared osteologically and morphologically to those of Eocene terrestrial mammals and Oligocene to present-day aquatic seals. It represents an intermediate stage but has already developed a very seal-like morphology [10]. The seal lineage must therefore be pushed back further than suggested in recent 
1 a

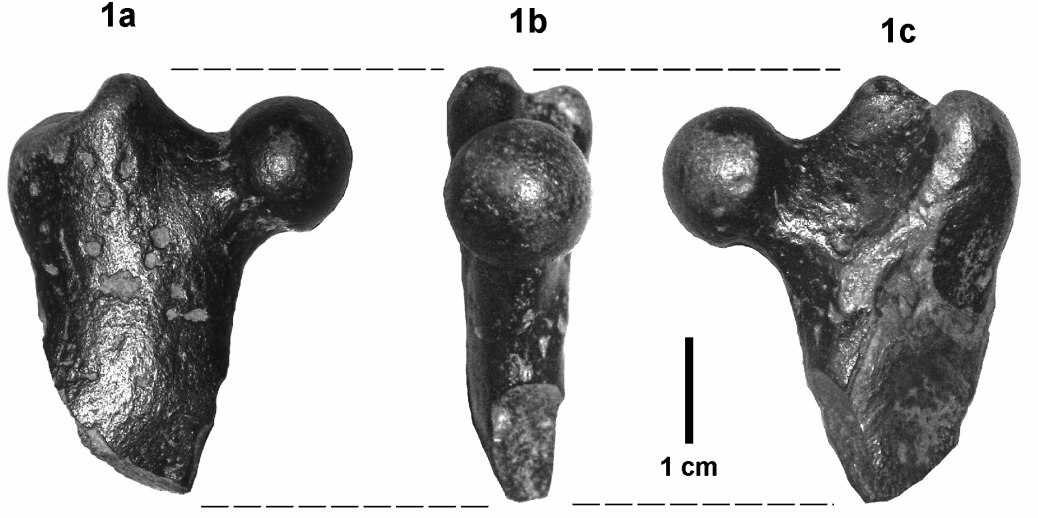



Early/Middle Eocene

Praephoca bendullensis

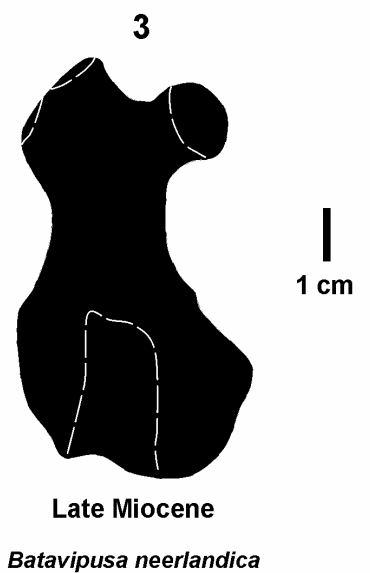

Batavipusa neerlandica



4

Phoca hispida

Figure 2. The world's oldest seal remains, from the Early Lutetian (early Middle Eocene) marine gravels at Dalum (north-western Germany), in a deltaic environment of the southern pre-North Sea basin, on the coast of central Europe. 1. Right half flattened pachyostotic femur with distinct head of Praephoca bendullensis nov. gen. nov. spec. (Holotype, SCB no. Mam-3), (a) cranial, (b) lateral inner view, (c) caudal. 3. Right femur of the Late Miocene seal Batavipusa neerlandica from the southern pre-North Sea basin (MAB). 4. Right femur of the modern ringed seal Phoca hispida (UAM).

publications, from the Eocene $[3,4]$ into the Paleocene and even to the Early Paleocene (Danian), from which no fossils of phocids or their ancestors have yet been recorded anywhere in the world.

Eocene. The femur from Dalum is the world's oldest record of an almost fully aquatic marine phocid. Because of the flattened and widened shape of the femur shaft the evolution to such morphology must have already started in the Paleocene, at the latest.

Oligocene. The oldest records of pinnipeds to have been reported in previous publications were from the Upper Oligocene (Chattian) of North America [1], but these authors failed to recognize or discuss the published phocid remains from the Upper Oligocene of northern Germany (a solitary rib from the southern North Sea basin at Bünde, in Doberg, Germany, was published with an unidentified "phocid rib" [12]). Pinnipeds are now well known from Upper Oligocene times in the northern hemisphere, although the amount of material recovered remains very limited.

Miocene. A younger phocid fossil from the Early Miocene (Burdigalian), which was found in the southern pre-North Sea basin of central Europe, has been described as Leptophoca amphiatlantica [13]. The Late Miocene (Tortonian-Messinian) phocid Batavipusa neerlandica [14] from the of the coast of the pre-North Sea basin in the Netherlands was also found in fully marine deposits, as described from the Paris Basin [15]. The newly discovered Puijila darwini [2], which has been suggested as a possible pinnniped ancestor, lived in the Arctic during the Miocene. Although this species was thought be a "missing link" it now seems likely that it represents a later adaptation to the aquatic life style within a separate lineage, which must have occurred more than 25 million years later than the phocid seal ancestor discovery reported herein, which has a minimum age of between 47 and $51 \mathrm{Ma}$, indicating that the pinnipeds must therefore have already been almost fully 
evolved by the middle of the Paleocene.

Pliocene. There is a much better fossil record for phocids in the Pliocene, which has already been discussed in several papers $[3,6,10,16]$.

Pleistocene to Present-day. The phylogeny of the pinnipedia and the DNA of extant species have recently been investigated by Arnaston et al. and Fukton et al. $[3,4]$. In today's southern North Sea basin two different phocid seal species occupy the sand banks and shallow marine environments, especially around the coastal islands of northern Germany and the Baltic Sea, these being the common seal Phoca vitulina [17] (Figure 1(c)) and the grey seal Halichoerus grypus [18].

\subsection{Palaeobiogeography and Habitat of Early Seals}

The presence of the earliest pinniped fossils on both the Atlantic coast (the phocids) and the Pacific coast (the otariids) of North America, together with the monophyly of the pinnipedia indicated by DNA analyses, led researchers to believe that they had originated on this continent [3,7]. However, the unrecognized fossil record from Europe, together with the new Early to Middle Eocene material, combine to suggest that they may have originated in the more protected shallow marine preNorth Sea Basin, with its extensive sandy coastlines, rather than on the steeper and deeper North American coastlines of the Middle Eocene that resulted from tectonic break-up and the opening up of the Atlantic Ocean [19]. The break-up of the American, European, and African continents and the opening up of the northern Atlantic Ocean [19] were certainly important factors in the evolution and distribution of the earliest seals. These seals may have originate in the cold Arctic regions and subsequently migrated southward (possibly seasonally) during the Early to Middle Eocene, through the North Sea basin to northern Europe and across the North Atlantic to the North American coast. The palaeobiogeographic separation of two lineages, the Atlantic [3] phocids and otariids [3] (including those from the North Sea coastlines discussed herein) and the North American Pacific coast phocids and otariids [3], may therefore have occurred some time later, during the Oligocene.

Since the fossil phocid seal record in Europe now extends from the Early to Middle Eocene into the Oligocene [10-12] and Miocene [13-15], the Phoca lineage (the northern Atlantic and North Sea phocids) appears more likely to have originated in Europe (in the southern pre-North Sea basin, where the oldest Praephoca bendullensis species was found) rather than in North America $[3,4]$.

Previous studies of pinniped origins, irrespective of whether they were based on their monophyly or diphyly
$[3,4]$, have assumed that pinnipeds originated on the shores of oceans or large bodies of water. This interpretation is also supported by the new material from the Eocene pre-North Sea basin presented herein, which was found in a coastal delta environment (Figures 1(a) and (b)). The sand and gravel banks that were present along the entire coastlines of the Armorican Massif, the Rhenish Massif, and the Bohemian Massif would have been ideal areas, both for catching fish and for reproduction.

Other authors [1] have suggested that the initial adaptation of the pinnipeds to an aquatic environment took place in a more restricted (even genetically $[3,4]$ ) and less exposed environment, and postulated that the pinnipeds entered the marine environment after an initial non-marine (lacustrine, riverine, or estuarine) phase of evolution, probably along the southern shores of North America, with the ancestors of extant phocids taking an eastward route into Atlantic waters and those of the otariids dispersing westward into the Pacific [3,13]. This model must now be revised on the basis of the palaeoenvironmental analyses completed on the Dalum site.

The earliest evidence of phocids with aquatic adaptations from the Middle Eocene of the southern pre-North Sea basin comes from the margins of a deltaic system, so that these may have still been fresh water forms, or perhaps have adapted to brackish water. In central Europe the transition from a terrestrial to a marine life style does not seem to be represented at Dalum as these Middle Eocene seals appear to have already been fully adapted shallow marine carnivores, but is supported by the evidence from their predators (see below). This suggests that their evolution may have started in the shallow marine pre-North Sea basin of central Europe, where many terrestrial tropical mammals evolved at that time on the mainland areas (Figure 1(a)), the fossils of which have been found at the UNESCO-World Heritage Site at Messel and at the Geiseltal fresh water lake site [8], both in Germany. Since such terrestrial ancestors of phocids are absent from the Middle Eocene at these sites, it can be assumed that the early seals were, at that time, pinnipeds already adapted to shallow marine conditions. This conclusion appears to be further supported by the presence of their predators.

\section{THE PHOCID PREDATORS}

In addition to the ideal coastal habitat of the $P$. bendullensis phocids, the suggestion that the Middle Eocene seals were already fully adapted to shallow marine conditions is supported by the abundant shark remains found at Dalum. This site contains many teeth of a smaller ancestor to the "great white shark" Procarcharodon auriculatus, and also less common larger, serrated teeth from a "megatooth shark" ancestor Carchharocles cf. sokolovi 
[5]. It would appear that sand and gravel banks in the coastal zones of the southern pre-North Sea basin may have already been serving as breeding areas for seals during the Eocene, as they have been from the Oligocene up to the present [16-18] and offer the earliest evidence of white shark hunting areas. This would also explain the quite unusually high quantity of white shark teeth in the Dalum region, which are much less well represented at other Belgian, English and French shark sites [20,21]. The development of the white shark lineages now appear to correlate very well with the appearance and evolution of the first larger marine mammals, and especially the seals, that formed their prey. The hunting of seals by white sharks, which is well known at the present time [22], thus appears to have had its origin in the Middle Eocene. As has been demonstrated herein for the seals, these predators also appeared after the Paleocene, and the ancestors of both the white sharks and the megatooth sharks [23] now appear to be well documented at the same time from the Dalum site, during the Early to Middle Eocene. The earliest sirenians [24] and toothed whales [25] also appeared at this time in the pre-North Sea basin; their existence at the Dalum site has not yet been proven, but is to be expected.

\section{ACKNOWLEDGEMENTS}

The discovery of the seal remain described herein was made by the hobby palaeontologist Mr. J. Bendull, who kindly allowed the specimen to be studied and a cast to be made. The project was sponsored by the Geopark TERRA. Vita (Mr. H. Escher), and the Osnabrück Landkreis. The company PaleoLogic was responsible for the field work and scientific research. I am grateful to The Kuhlhoff education center leaders (Mr. A. Bruns and Mr. W. Hollermann), and the mayor of Bippen, Mr. $\mathrm{H}$. Tolsdorf, for managing the installation of a field sieving laboratory. Finally, I would also like to thank H. Felker, another local hobbypalaeontologist, who provided support, helped with sieving the material, and allowed access to his large collection (obtained over 25 years from both Dalum and Bippen localities) for comparisons, especially of the white shark tooth material. Finally E. Manning supported much with the spell-check.

\section{REFERENCES}

[1] Koretsky, I. and Sanders, A.E. (2002) Paleontology of the late oligocene ashley and chandler bridge formations of South Carolina, 1: Paleogene pinniped remains; the oldest known seal (Carnivora: Phocidae). Smithson. Contributions to Paleobiology, 93, 179-183.

[2] Rybczynski, N., Dawson, M.R. and Tedford, R.H. (2009) A semi-aquatic Arctic mammalian carnivore from the Miocene epoch and origin of Pinnipedia. Nature, 458, 1021-1024. doi:10.1038/nature07985

[3] Arnason, U., Gullberg, A., Janke, A., Kullberg, M., Lehman, N., Petrov, E.A. and Väinölä, R. (2006) Pinniped, phylogeny and a new hypothesis for their origin and dis- persal. Molecular and Phylogenetic Evolution, 41, 345354. doi:10.1016/j.ympev.2006.05.022

[4] Fulton, T.L. and Strobeck, C. (2010) Multiple markers and multiple individuals refine true seal phylogeny and bring molecules and morphology back in line. Proceedings of the Royal Society B, 277, 1065-1070. doi:10.1098/rspb.2009.1783

[5] Diedrich, C. (2011) Early Eocene (Lutetian) coastal sharkrich palaeoenvironments of the southern European North Sea Basin-The marine Fürstenau Fm biodiversity and their earliest white shark ancestors. International Journal of Oceanography, in press.

[6] Ray, C.E. (1977) Geography of phocid evolution. Systematic Zoology, 25, 391-406. doi:10.2307/2412513

[7] Koretsky, I.A. and Barnes, L.B. (2006) Pinniped evolutionary history and palaeogeography. In: Csiki, Z., Ed. Mesozoic and Cenozoic Vertebrates and Paleoenvironments - Tribute to the Career of Professor Dan Grigorescu, 143-153.

[8] Schaal, S. and Ziegler, W. (1988) Messel—Ein schaufenster in die geschichte der erde und des Lebens: Waldemar Kramer, Frankfurt a. M.

[9] Franzen, J.L. and Mörs, T. (2007) Das nördlichste Vorkommen paläogener Säugetiere in Europa. Paläontologische Zeitschrift, 81, 447-456.

[10] Friant, M. (1947) Recherches sur le fémur des Phocidae. Bulletin du Musée Royal d'Histoire Naturelle Belgique, 23, 1-51.

[11] Ericson, P.G.P. and Storå, J. (1999) A manual to the skeletal measurements of the seal genera Halichoerus and Phoca (Mammalia: Pinnipedia). Department of Vertebrate Zoology, Swedish Museum of Natural History, Stencil, Stockholm.

[12] Springhorn, R. (1984). Das oligozän in ostwestfalenlippe. Lippische Mitteilungen für Geschichte und Landeskunde, 53, 253-169.

[13] Koretsky, I.A., Ray, C.E. and Peters N. (2011) Miocene seals of the Netherlands part I: A new species of Leptophoca (Carnivora, Phocidae, Phocinae) from both sides of the North Atlantic Ocean. In: Jacobs, B. and Taylor, L.H., Eds., Paleontologica Electronica, Tribute to the career of Charles Repenning, in press.

[14] Koretsky, I.A. and Peters, A.M.M. (2008) Batavipusa (Carnivora, Phocidae, Phocinae): A new genus from the eastern shore of the North Atlantic Ocean (Miocene seals of the Netherlands, part II). Deinsea, 12, 53-62.

[15] Ginsburg, L. and Janvier, P. (1999) Les phoques (phocidae, pinnipedia, carnivora, mammalia) des faluns miocene de l'anjou. Bulletin de la Societé Sciences Naturelle l'Ouest France N.S., 21, 169-178.

[16] Koretsky, I.A. and Ray, C.E. (2008) Phocidae of the Pliocene of Eastern North America. Virginia Museum of Natural History Special Publications, 14, 81-139.

[17] Burns, J.J. (2002) Harbor seal and spotted seal Phoca vitulina and P. largha. In: Perrin, W.F., Wursig, B. and Thewissen, J.G.M., Eds., Encyclopedia of Marine Mammals, Academic Press, London, 552-560.

[18] Thompson, D., Hammond, P.S., Nicholas, K.S. and Fedak, M.A. (2009) Movements, diving and foraging behaviour of grey seals (Halichoerus grypus). Journal of Zoology, 224, 223-232. doi:10.1111/j.1469-7998.1991.tb04801.x 
[19] Ziegler, P.A. (1999) Geological atlas of Western and Central Europe. Shell, Amsterdam.

[20] Lériche, M. (1906) Contribution à lètude des poisons fossils du Nord de la France et des regions voisines. Mémoires de la Société Geologique Nord, 5, 1-430.

[21] Casier, E. (1966) Fauna ichthyologique du London Clay. British Museum Natural History London, 1966, 1-496.

[22] Van den Eeckhaut, G. and De Schutter, P. (2009) The Elasmobranch fauna of the Lede Sand Formation at osterzele (Lutetian, Middle Eocene of Belgium). Palaeofocus, 1, 1-57.
[23] Kimley, A.P. and Ainley, D.G. (1996). Great white sharks: The biology of Carcharodon carcharias. Academic Press, San Diego.

[24] Zalmout, I.S., Ul-Haq, M. and Gingerich, P.D. (2003) New species of Protosiren (Mammalia, Sirenia) from the Early to Middle Eocene of Balochistan (Pakistan). Contributions of the Museum Paleontology University Michigan, 31, 79-87.

[25] Thewissen, J.G.M. (1998) The emergence of whales: Evolutionary patterns in the origin of Cetacea. 